\title{
The efficiency of a bolter miner - requirements and constraints
}

\begin{abstract}
This paper presents an analysis of the requirements and constraints concerning the efficiency of the application of coal roadway development systems with bolt roof supports by means of specialized mining, loading and bolting machines. In some cases, machines of this type can achieve very good roadway development results measured with the daily/weekly/monthly advancing of the face. An attempt was made to indicate the requirements to be met in order to achieve the expected results, as well as the factors limiting the obtained results of gateroad development operations.
\end{abstract}

Key words: longwall systems, gallery development, roadheading, bolt support (roof bolting), bolter miner, coal mining

\section{INTRODUCTION}

Bolter miners appeared about 30 years ago as specialized equipment intended for drilling coal and coal-and-rock headings in hard coal mines that used to operate longwall mining systems. Previously, the search for a solution to the following problem had been carried out for many years: how to increase the advancing of drilling longwall gateroads and thus the increasing advancing of longwalls? The change in the perception of mechanized longwalls after they had been implemented in US coal mining [1,2], then in Australia and subsequently in other countries (Russia, China and others) led to an increase in the daily production of longwalls and thus an increase in their daily advancing rates. This had to be followed by an increase in the daily advancing of the gateroad faces, as each subsequent longwall must be prepared before the previous one reaches its stop line. The principle of "time is money" is fully confirmed with regard to the preparation of the longwall panel for mining operations; very expensive equipment of a highly efficient longwall complex cannot wait unproductively for the preparation of the headings for the subsequent longwall [3]. Great attention has been paid to the issue of achieving high advancing rates in roadway development operations also in Poland $[4,5]$, and a lot of attention worldwide has been paid to improving the efficiency of gateroad development operations with the use of bolter miners [6-16]. In the most technologically advanced and productive hard coal mines in the world, it has become common practice to use a bolt support (roof bolting) as a less expensive method of securing the gateroads (headings). The combination of technical solutions enabling mechanical cutting in coal and coal-and-rock faces with the quick installation of the bolt support (roof bolting) in the heading face resulted in the creation of highly specialized machines - bolter miners. These machines enable a very high gateroad development progress rate - the best recorded result is approx. $2500 \mathrm{~m} / \mathrm{month}$, obtained in 2018 at the Daliuta mine (Shenhua Shendong Group) [17] in China. In favorable mining and geological conditions, well-prepared gateroad faces are able to achieve advancing/progress rate of 6-8 m/h. In 2019, gallery drivage with the Komatsu/ Joy Global 12CM30 bolter miner [18] was started in Poland for experimental purposes.

This paper presents an analysis of the requirements and constraints for the effective use of bolter miner machines. 


\section{ORIGINS AND CONSTRUCTION OF BOLTER MINERS}

Bolter miners are the effect of many years of searching for a solution to the problem of high performance of mechanical mining in coal faces and the need to secure the roof and the sidewalls of the headings subject to drilling as rapidly as possible.

\subsection{Before the invention of bolter miners}

In its current design, the bolter miner is a combination of a continuous miner with a multi-head bolting device on one undercarriage (chassis).

In the past, attempts were made to separate in time and space the face mining (cutting) from the roof bolting using a powered roof support as a temporary support between the cutting area (face) and the roof bolting area. This solution, applied in the headings of the room and pillar system in the USA [19, 20], did not prove its advantages and as a result, it was quickly abandoned. In European mining, attempts were been made to use face-drilling machines with mechanical cutting and continuous (follow-up) roof bolting with one machine (AVSA), but also these attempts were unsuccessful.

For the needs of the dynamically developing Australian coal mining industry, the Joy company created a device called Joy Sump Shearer (JSS) in the 1980s (Fig. 1) [21]. The machine was intended for use in drilling headings with rectangular-arched cross-sections, with roof bolting in the immediate vicinity of the face $(1.5 \mathrm{~m})$. Two bolters were used and the heading cross-section was chosen due to the optimal use of the bolters. The machine was equipped with two cutting heads mounted on the arms, just like in longwall shearers.

These heads (cutting units) enabled cutting the roof (with rock cutting) with an arch roof support. This solution minimized the volume of the roof rock cut, as at that time, the coal walls of $2.2-2.8 \mathrm{~m}$ high were mined in Australia. Due to the increase in the thickness of the exploited seams, and the limited benefits of using the JSS, this solution was abandoned.

In the USA and Australian coal mining, the longwall system, especially retreat LW, is regarded as the next stage in the development of the room-and-pillar system with pillar recovery. Since the 1940s, various types of machines have been used for the mechanical mining of coal in these systems, which unlike mechanization systems with blasting (use of explosives), were called Continuous Miners [5]. For several decades, cutter-loaders with linear cutting head across the entire web have been dominant among these machines. In the room-and-pillar mining systems, these machines work in a multi-face system with alternate roof cutting and roof bolting with a separate self-propelled bolting machine. This solution was also used to gateroad development for preparing LW panels. In practice, however, it turned out that there were large losses of time related to the replacement of machines in the face - after cutting the whole undisturbed soil (coal body) to a safe depth, the continuous miner had to be reversed from the face to pass and make space for the bolting machine. An alternative, often compelled by mining and geological conditions, was roof bolting with manual bolters immediately after the roof was exposed.

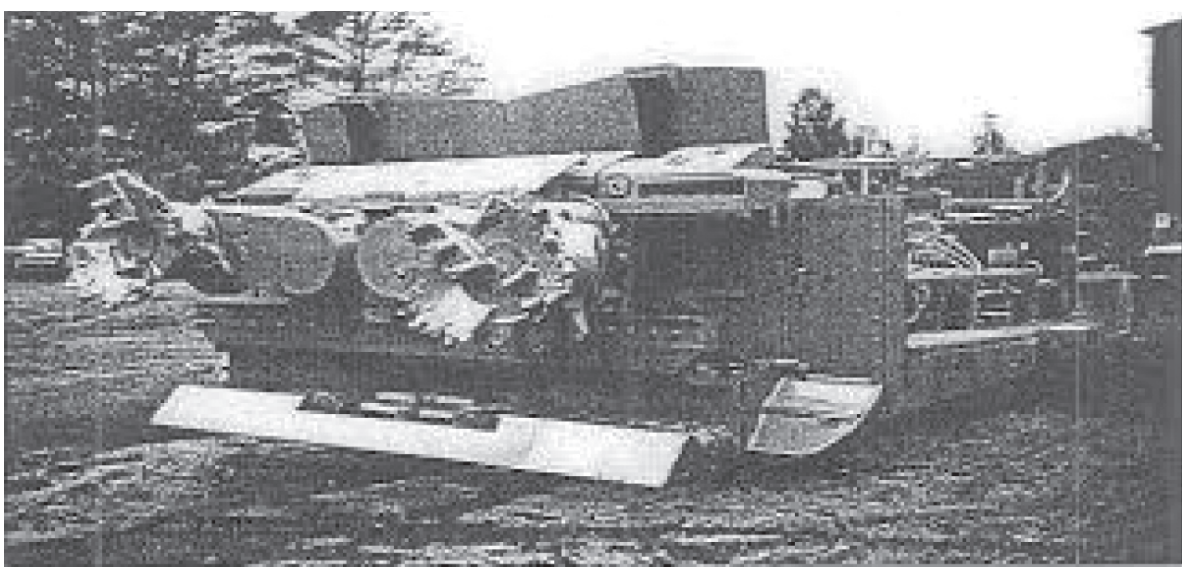

Fig. 1. Joy Sump Shearer [21] 


\subsection{The idea of the bolter miner}

At the end of the 1980s, the idea was born to equip the Continuous Miner shearer with a bolting station that would enable simultaneous drilling and bolting the roof and the sidewalls of the headings with several bolters. The first ABM-20 device of this type, used in the Australian Tahmoor mine [3], was developed by Voest Alpine Bergtechnik (now: Sandvik). The implementation was successful and the bolter miner type very quickly became popular in the global coal mining industry, wherever there have been conditions for their effective use. Nowadays, these machines are used on a large scale in mines extracting hard coal with a longwall system in Australia, the USA, China and Russia. Individual machines are op- erated in other countries, while in the declining European coal mining industry they have been implemented in the Czech Republic and, recently, in Poland. High power of the linear cutting head and the machine stability resulted in the fact that, similarly to the borer miners, bolter miners have been used in the exploitation (extraction) of some other soft minerals (rock salt, sylvinite, trona) in mining systems with long gates.

Nowadays, at least 3 global manufacturers offer bolter miner machines (Fig. 2).

Similar machines are offered by other manufacturers, but there is no information about their use.

Since the first bolter miners appeared, they have been enhanced to increase drilling efficiency, and improve safety and ergonomics.

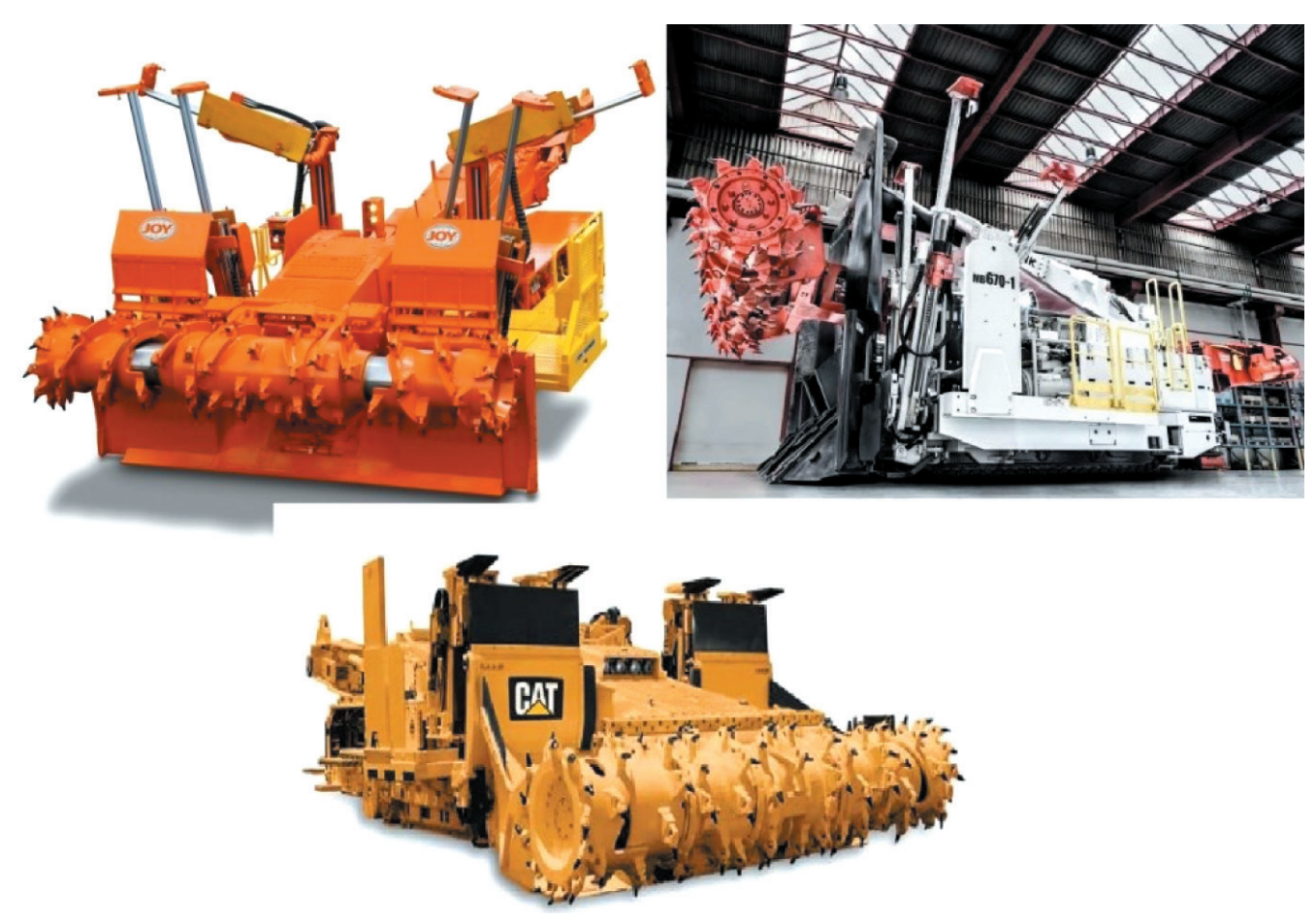

Fig. 2. Bolter miners produced by Joy 12CM30, Sandvik MB670 and CAT CM845 [22-24]

\section{TECHNICAL SYSTEM OF THE FACE (GATE END) WITH THE BOLTER MINER}

During the development of bolter miners, relevant experience was gained and a technical system was improved to enable the very effective drilling of coal and rock and stone headings with a rectangular cross-section with the use of a bolt support (roof bolting). The roadheader has been the key element of the system.

\subsection{Design and basic features of the bolter miners}

The bolter miner is a combination of two devices on a common undercarriage (chassis) [25-27]:

- A mining and loading machine enabling the haulage of the excavated material beyond the face (machine),

- A bolting station equipped with several bolting heads, enabling bolting the roof and sidewalls simultaneously. The number of bolters varies from 4 to 6 . 


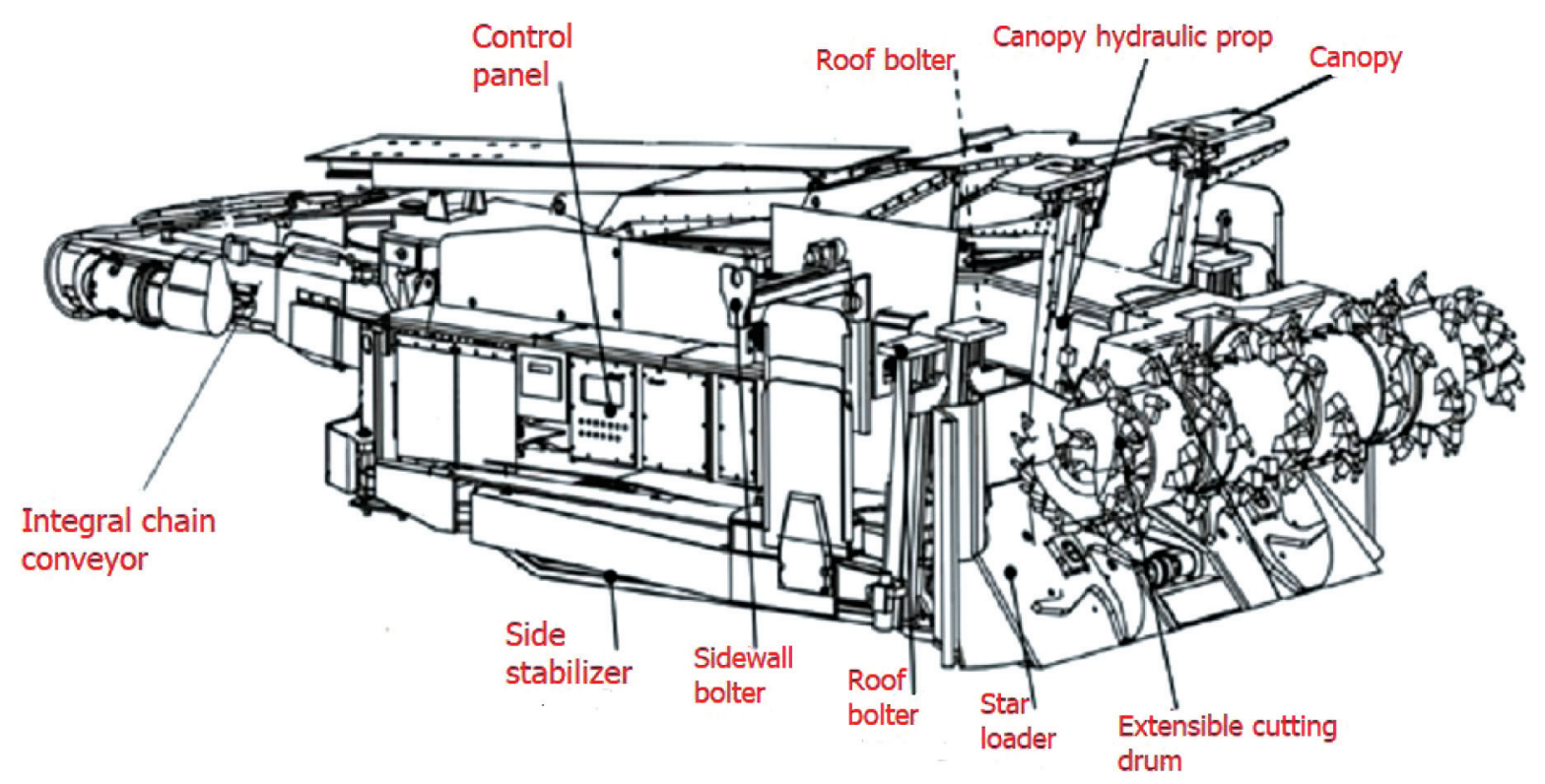

Fig. 3. Basic components of the bolter miner (own study based on [18])

The basic design assumption was to minimize the time of the basic groups of operations performed in the face by increasing the cutting efficiency and simultaneous drilling and bolting with many anchors. The basic components of the bolter miner by Sandvik are shown in Figure 3.

Unlike similar continuous miners, the characteristic feature of the bolter miner machines is an extendible cutting head. This solution is designed to enable the bolter miner to be reversed after a long gallery has been drilled in the event of its horizontal convergence. The desire to improve the efficiency of drilling and extend the share of time devoted to mining/cutting meant striving for operations of cutting/loading the excavated material and roof and sidewalls bolting to be performed at the same time (in parallel). While bolting, the bolters must be kept in a stable position. Sandvik bolter miners are equipped with an extendable cutting and loading unit (organ/unit + loader table) enabling simultaneous cutting and bolting. In order to ensure the stability of the undercarriage with the bolters, it is stabilized to the sidewalls by means of sprags/tie-beams and to the roof by means of a temporary support canopy. Three extendable supports are intended to facilitate the machine leveling.

Machines from other manufacturers have not been equipped with an extendable cutting and loading unit (sump) and therefore the possibility of simultaneous cutting and bolting is practically impossible - the duration of the basic drilling cycle is shortened by reducing the duration of individual activities and operations.
The machine is equipped with an integrated dust suppression system.

Due to the high power of the cutting unit motors (over $300 \mathrm{~kW}$ in total), bolter miner machines must have a relatively large weight (of $80 \mathrm{Mg}$ to over $100 \mathrm{Mg}$ ) with limited overall dimensions to maintain stability. This results in relatively high pressure on floor (ground pressure). Due to the inability to move the cutting unit horizontally, it is necessary to maneuver the bolter miner to achieve its precise positioning before proceeding with cutting, and in particular with bolting operation. Weaker floor strata means that the bolter miner may get stuck, which implies the resulting loss of time dedicated to mining/bolting operation.

It should be noted that bolter miners are very sensitive to the transverse inclination of the seam (permissible transverse inclinations do not exceed $5^{\circ}$ ) as there are problems with maintaining the directional stability of the machine. In addition, excessive transverse inclinations of the floor causes further problems with the transport of the equipment and the operation of systems installed in such headings (gateroads).

\subsection{Output haulage systems and supply systems in the face}

As a standard, in the field of haulage operations the bolter miners work with the shuttle cars that transport the material to a self-propelled feederbreaker station, as shown in Figure 4. 


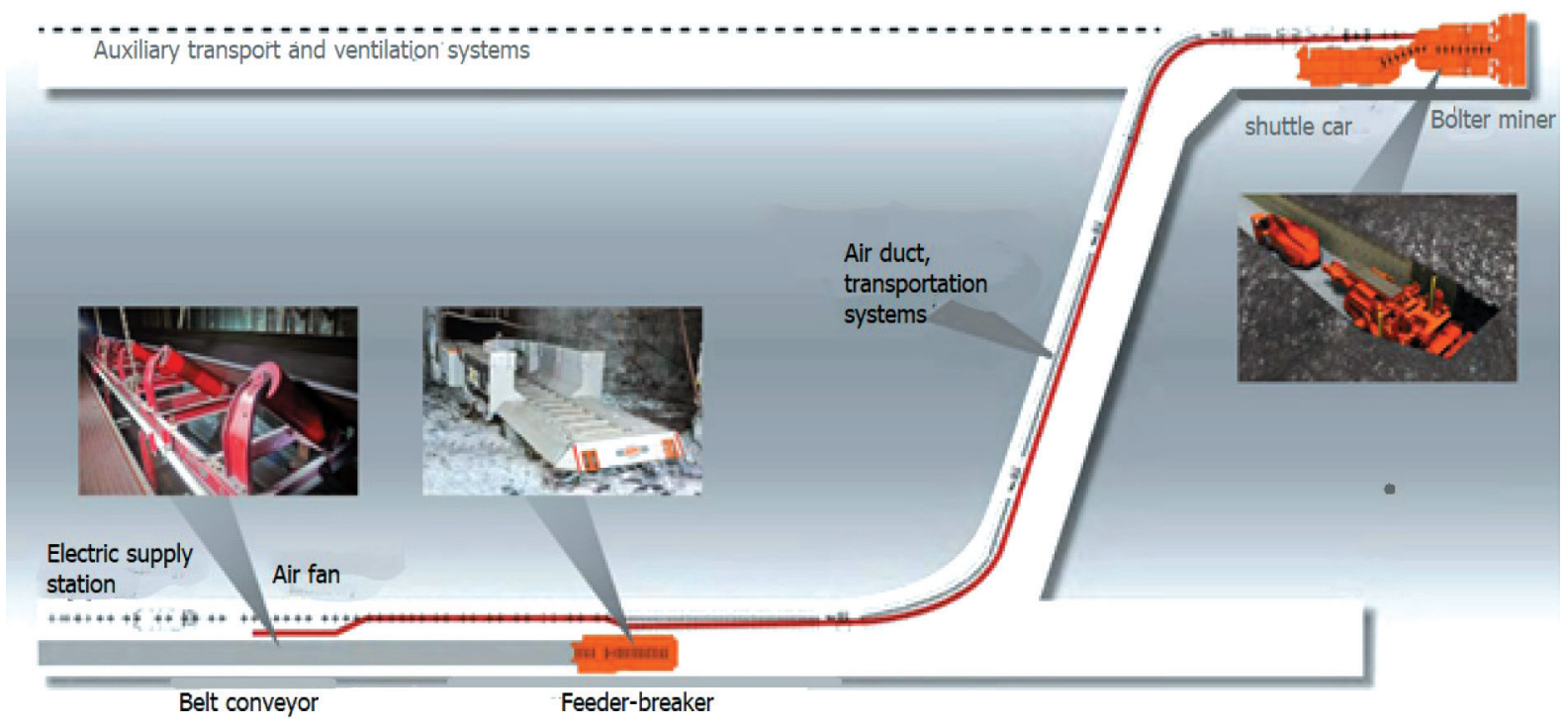

Fig. 4. The most widespread technological system/arrangement of the face (gate end) with the bolter miner (own study based on [22])

The feeder-breaker station is intended to prepare the output for a long-distance transport with a belt conveyor by crushing it and aligning the output stream. The advantage of this solution is that it makes the cutting machine operation independent of the continuity of the operation of the haulage system (conveyor belts). The shuttle car (sometimes two or more) perform function of a "flexible connection" a movable retention reservoir (-s).

For several years, attempts have been made to apply flexible conveyor trains (e.g. the Komatsu FCT system) [23] to transport the output, with various effects.

This solution has not been applied in Australian mining, but the applications of this solution in the US coal mining have been described, where the systems of three or even more parallel gateroads interconnected by cross headings occur (Fig. 5).
Less common are solutions with the attachment of a suspended feeder (belt or armoured conveyor) from the machine, intended for reloading the output into the belt conveyor, because such a solution makes it difficult to position the bolter miner and, in addition, it changes the floor pressure distribution - in conditions of weaker floors, this may be an additional cause of floor destruction and the machine getting stuck. Any solution with some form of output retention between the bolter miner and the belt haulage is a favorable solution due to the transport characteristics of the equipment. The bolter mined has a high instantaneous capacity (up to $35 \mathrm{Mg} / \mathrm{min}$ ), it feeds an output stream at this intensity for a few minutes. Without retention, the stationary belt conveyor would have to have a similar instantaneous transport capacity, which means a significant oversizing of the device, given the operating characteristics of the belt conveyors.

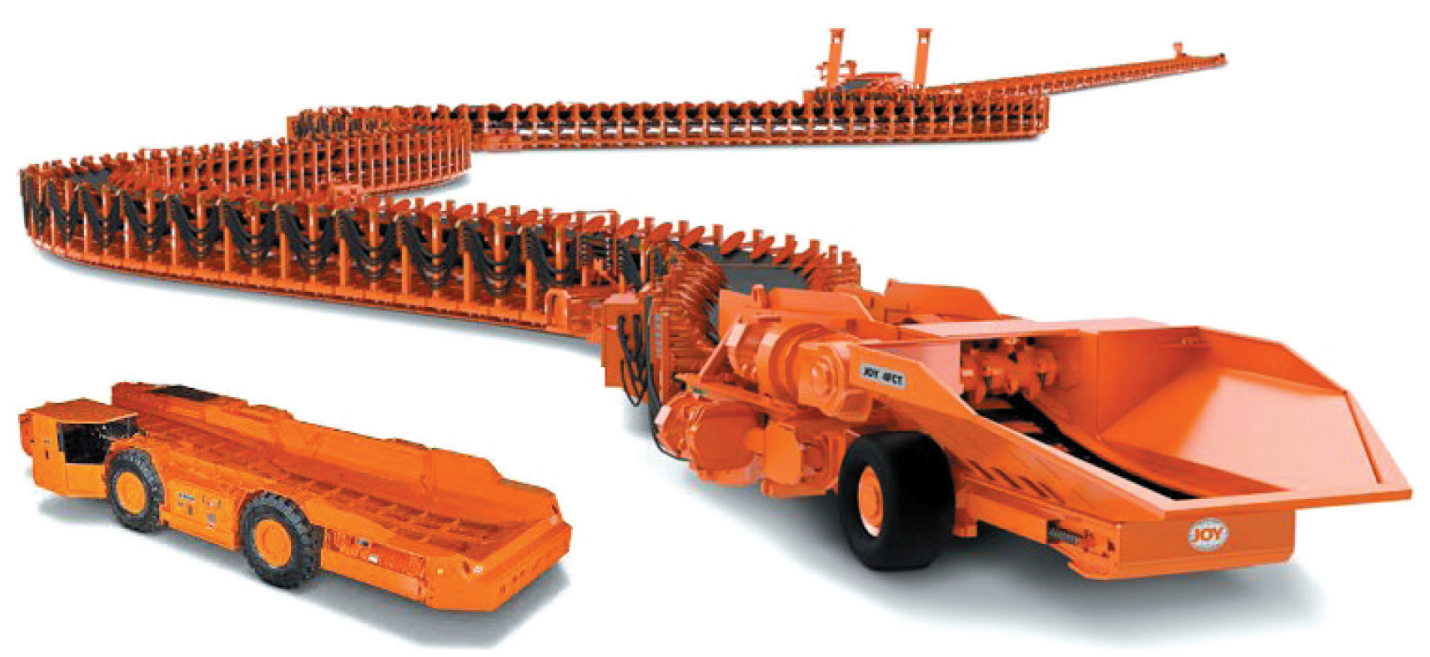

Fig. 5. Flexible belt conveyor FCT by Komatsu/Joy Global and Shuttle Car [23] 
The advantage of roof \& sidewalls bolting is significantly reduced material demand compared to the headings drilled with a steel roof support (as arches), and thus minor requirements as for transport systems.

\subsection{Other systems}

The bolter miner places high demands on the media supply.

Therefore, it is necessary to supply process water with appropriate parameters (flow capacity, pressure and purity) to the face.

Due to the high power of the electric motors installed on the bolter miner machine, high requirements are also placed on the power network.

A technical system indispensable in drilling headings (gateroads) is the face ventilation system as the so-called auxiliary ventilation system consisting of a fan built into a streamline airflow (i.e. an airflow forced to move by fans installed mostly on the surface of the underground mine). Fresh air is supplied to the face from the fan through the ventilation ducts (exhaust air extraction is less frequently used in the case of bolter miners).

\section{REQUIREMENTS AND CONSTRAINTS FOR THE USE OF BOLTER MINERS}

For the effective operation of the bolter miners, it is necessary to meet the technical requirements, including mining and geological conditions.

\subsection{Requirements for the bolter miners}

Figure 6 shows the basic groups of requirements for the effective operation of the bolter miners.

The above-mentioned requirements place high demands on the selection of the mechanization system for a heading to be drilled, just at the planning and design stage, as well as the selection of the operating staff and relevant training of the latter.

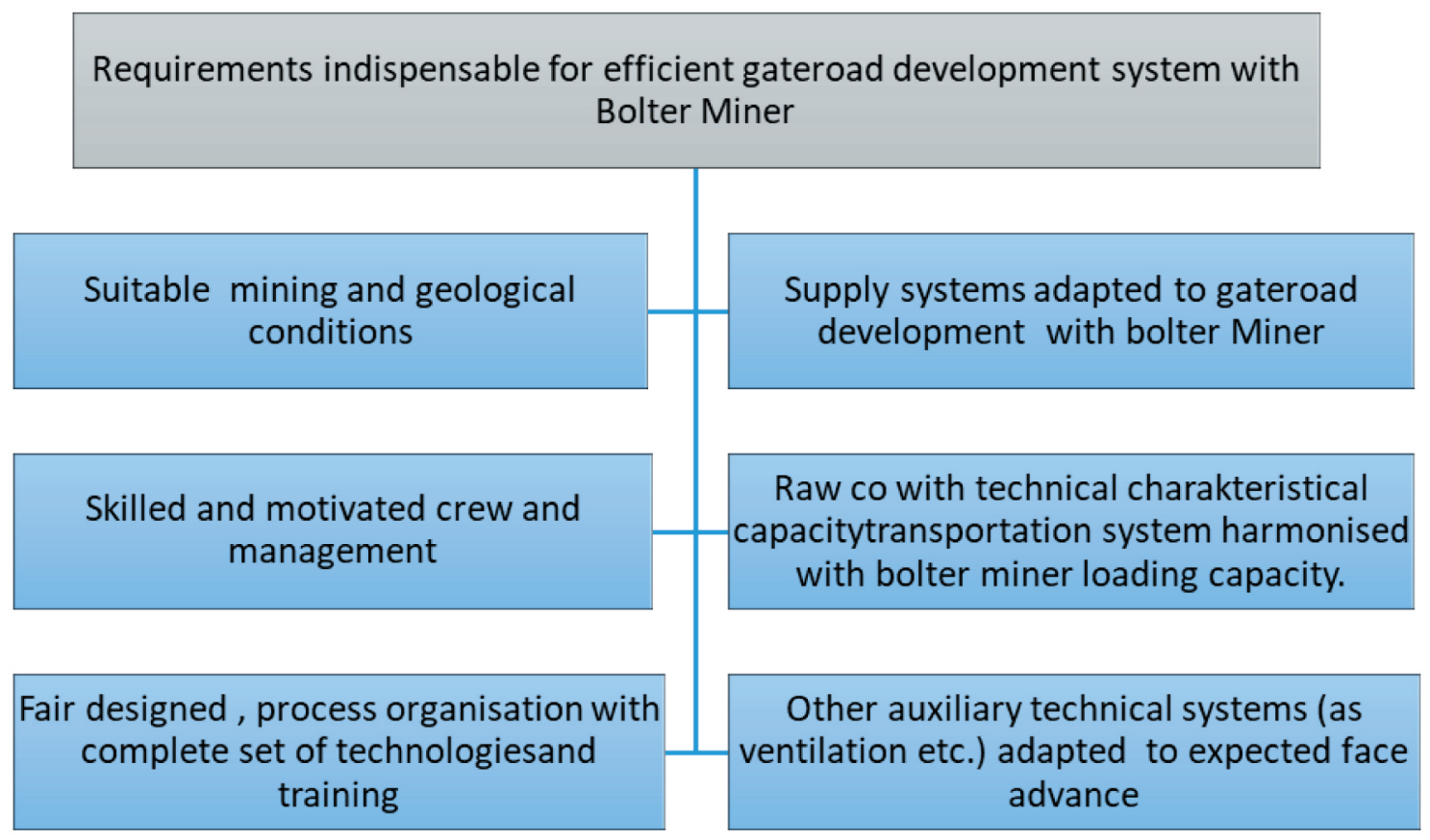

Fig. 6. Requirements for the effective operation of the bolter mine

\subsection{Factors limiting the efficiency of the heading drilling with a bolter miner}

Each technical system in mining has its own design constraints (usually defined as permissible operating parameters). The operation of such a system in conditions where the permissible operating parameters are exceeded is usually the reason for a decline in operation results. All mechanization systems in mining are exposed to factors limiting the potential technical capabilities of the system, as shown in Figure 7. 


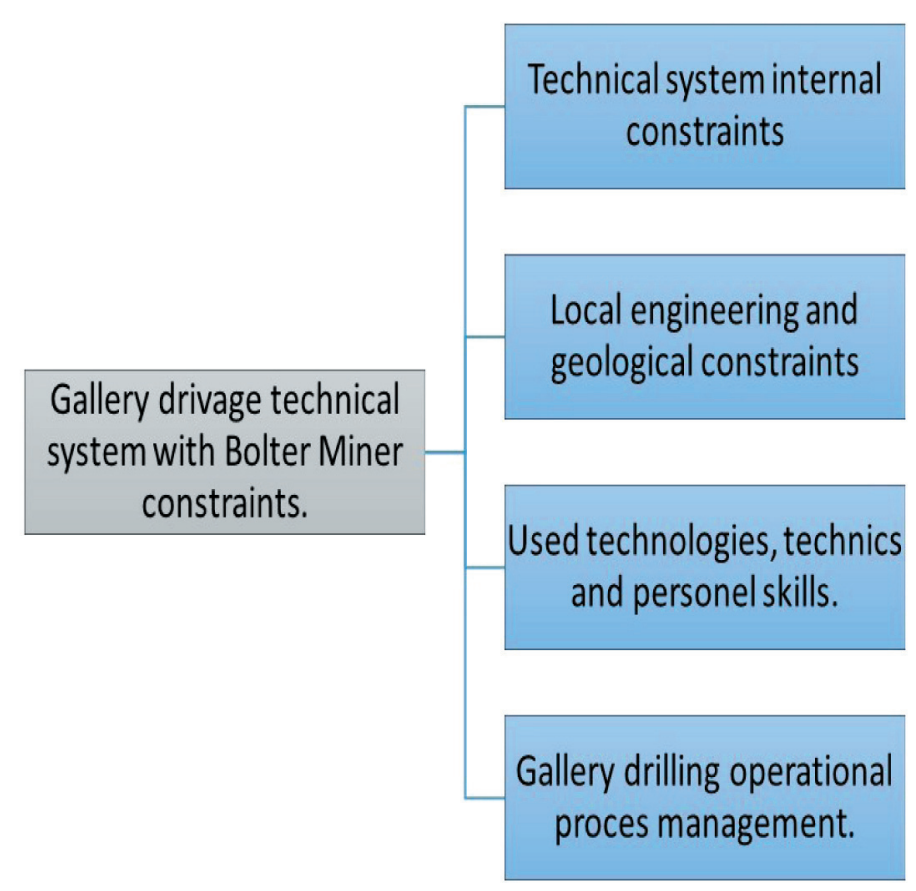

Fig. 7. Factors limiting the efficiency of the technical system of the heading drilled with the bolter miner (own study based on [9, 29, 30])

In the case of applying mechanization systems with bolter miners when drilling headings, there is a very high degree of sensitivity to the occurrence of these constraints. This is due to the high specialization of the mining machine intended to operate in a relatively narrow spectrum of mining and geological conditions. The time of making the bolt roof support, significantly affecting the duration of the basic cycle of the heading drilling, requires an open approach in the design of the bolt roof support - apart from ensuring the safety and stability of the heading in its life cycle, it is important to apply solutions that shorten the duration of the entire bolting operation.

\section{SUMMARY}

The high power of the linear cutting head of the bolter miner creates the potential for a high advancing rate (daily, monthly, etc.) to be achieved, but it is possible in a relatively narrow spectrum of mining and geological conditions, with cooperating technical systems adapted to the capabilities of the bolter miner, and high skills of operating staff, as well as appropriately planned, organized, and managed process of heading drilling. Failure to meet these requirements is a factor that reduces the results obtained.

The prerequisite is the use of this machine in appropriate mining and geological conditions, which requires careful identification of these conditions before making a decision. It is also important that there are good conditions for the use of the bolt roof support - in some conditions it may turn out that the labor consumption of making stable and safe roof bolting will require a different solution to be applied.

The decision on the application of a bolter miner requires a very careful cost-benefit analysis.

\section{References}

[1] Barczak T.M.: The History and Future of Longwall Mining in the United States, U.S. Department of the Interior, Bureau of Mines, 1992.

[2] Peng S.S.: Longwall Mining, $3^{\text {rd }}$ Edition, CRC Press/Balkema, Leiden 2020.

[3] www.coalage.com/features/faster-roadway-development/ [12.11.2020].

[4] Przybyła H., Chmiela A.: Technika i organizacja $w$ robotach przygotowawczych, Wydawnictwo Politechniki Śląskiej, Gliwice 2002.

[5] Zając E.: Organizacja produkcji w kopalni $w$ kopalni węgla kamiennego, Śląskie Wydawnictwo Techniczne, Katowice 1994.

[6] ACARP: Final Report: Australian Roadway Development Current Practises, Australian Coal Association Research Program, 17 October 2005.

[7] Baafi E., Gray G., Porter I., Rojas O.: The Modelling of Roadway Development to Support Longwall Mining, Australian Coal Association Research Program (ACARP). Simulation Modelling Services Pty Ltd, School of Civil, Mining and Environmental Engineering University of Wollongong, November 2009, http://www.undergroundcoal.com.au/roadway/pdf/roadsim_final_report.pdf [11.01.2019]. 
[8] Banarjee S.: Performance evaluation of continuous miner based underground operation: An OEE based approach, "New Trends of Production Engineering" 2019, 2, 1: 596-603.

[9] Kizil M.S., McAllister A., Pascoe R.: Simulation of Development in Longwall Coal Mines, [in:] $11^{\text {th }}$ Underground Coal Operators Conference, University of Wollongong \& Australiasian Institute of Mining and Metallurgy, 2011: 91-98.

[10] Leeming J., Flook S., Altounyan P.: Bolter miners for longwall development, "Gluckauf" 2001, 137, 11: 633-638.

[11] Ma P., Qian D., Zhang N., Shimada H., Pan D., Huang K.: Application of bolter miner rapid excavation technology in deep underground roadway in inner Mongolia: A case study, "Sustainability" 2020, 12, 7, art. no. 2588.

[12] Singh R.D.: Principles and practices of modern coal mining, New Age International Publishers, New Delhi 1997.

[13] Van Duin S., Donnelly P., Oxley I.: Automated bolting and mesh handling on a continuous miner, [in:] Final Report ACARP PROJECT C17018 - Stage 1, University of Wollongong, Wollongong (NSW, Australia) 2011.

[14] Wang H.: Present Status and Development of Mine Roadway Heading Technology and Equipment in China Coal Mine, "Journal of Coal Science and Technology" 2010, 38, 1: 57-62.

[15] Zhang D.: Development status and key technology of intelligent rapid driving technology in coal seam roadway, "Journal of Coal Engineering" 2018, 50, 5: 56-59.

[16] Wallman D.: Results of the First Trail Single Entry at Ellalong Colliery, ACIRL Report No. PR82.1 1982.

[17] Gao D., Liu Y., Luo W.: The Application of Speedy Drivage System in Daliuta Coal Mine, "IOP Conference Series: Materials Science and Engineering" 2019, 490, 062073, https:// iopscience.iop.org/article/10.1088/1757-899X/490/6/062073/ pdf [10.12.2019].

[18] Korski J.: Zastosowanie kombajnów typu Bolter Miner w warunkach polskich kopalń - uwarunkowania i ograniczenia, "Inżynieria Górnicza" 2018, 4: 40-48.

[19] Korski J: Tymczasowe obudowy zmechanizowane w drażeniu wyrobisk korytarzowych, [in:] D. Prostański, B. Polnik (red.): Innowacyjne techniki i technologie dla górnictwa: bezpieczeństwo - efektywność - niezawodność, Instytut Techniki Górniczej KOMAG, Gliwice 2020.
[20] Lesiecki W., Regulski W.: Urabianie złóż. Część 3. Urabianie kombajnami, Wydawnictwo "Śląsk", Katowice 1957 ("Górnictwo", t. 5).

[21] Ward B., Down M.: Gateroad Development in Thick Seams Using the Joy Sump Shearer, [in:] N. Aziz, B. Kininmonth, eds., Proceedings of the 1998 Coal Operators' Conference, Mining Engineering, University of Wollongong, 18-20 February 1998, https://ro.uow.edu.au/coal/274 [20.12.2020].

[22] CAT, https://www.cat.com/en_US/by-industry/mining/ underground-mining.html [20.12.2020]

[23] KOMATSU, www.mining.komatsu/underground-mining/ room-pillar-entry-development [27.11.2020].

[24] SANDVIK, www.rocktechnology.sandvik/en/products/ mechanical-cutting-equipment/ [27.07.2018].

[25] Klich A. (red.): Maszyny i urządzenia dla inżynierii budownictwa podziemnego. Wyrobiska korytarzowe $i$ szybowe $w$ górnictwie, "Ślask" Sp. z o.o., Wydawnictwo Naukowe, Katowice 1999.

[26] Kotwica K., Klich A.: Maszyny i urządzenia do drażenia wyrobisk korytarzowych $i$ tunelowych, Instytut Techniki Górniczej KOMAG, Gliwice 2011.

[27] Price D.: Demonstration of continuous cutting/bolting/ rib-bolting development machine (the Voest-Alpine ABM 20 Bolter Miner), “Australia's Journal of Coal Mining Technology and Research" 1992, 35: 3-12.

[28] Korski J., Tobor-Osadnik K., Wyganowska M.: Internal Client and Efficiency in the Mining Process. World Multidisciplinary Earth Sciences Symposium (WMESS 2018) IOP Conference Series: Earth and Environmental Science 2019, 221, DOI: $10.1088 / 1755-1315 / 221 / 1 / 012102$.

[29] Korski J.: Czy podejście procesowe może podnieść efektywność polskiego górnictwa węgla kamiennego?, [in:] Materiaty konferencyjne XXVI Szkoty Eksploatacji Podziemnej, Kraków 22-24.02.2017.

JACEK KORSKI, Ph.D., Eng. Famur S.A. ul. Armii Krajowej 51, 40-698 Katowice, Poland JKorski@famur.com.pl

(C) 2020 Author. This is an open access publication, which can be used, distributed, and reproduced in any medium according to the Creative Commons CC-BY 4.0 License. 


\title{
Efektywność kombajnu chodnikowego typu Bolter Miner - wymagania i ograniczenia
}

\begin{abstract}
W artykule przeprowadzono analizę wymagań $i$ ograniczeń efektywności stosowania systemów drążenia chodników w węlu z obudowa kotwowa za pomoca wyspecjalizowanych maszyn urabiająco-ładująco-kotwiących. Maszyny tego typu uzyskują w niektórych przypadkach bardzo dobre wyniki drą̇enia mierzone dobowym/tygodniowym, miesięcznym postępem przodka. Podjęto próbę wskazania wymagań, których wypetnienie przyczynia się do uzyskania oczekiwanych wyników oraz czynników ograniczających uzyskane efekty drą̇̇enia.
\end{abstract}

Słowa kluczowe: system ścianowy, kombajny chodnikowe, drążenie wyrobisk korytarzowych, obudowa kotwowa, Bolter Miner

\section{WPROWADZENIE}

Kombajny chodnikowe typu Bolter Miner pojawiły się około trzydziestu lat temu jako urządzenia wyspecjalizowane do drążenia węglowych i węglowo-kamiennych wyrobisk korytarzowych w kopalniach węgla kamiennego stosujących ścianowe systemy wydobywcze. Wcześniej przez wiele lat poszukiwano rozwiązania problemu: jak zwiększyć postęp drążenia wyrobisk przyścianowych w konsekwencji rosnących postępów ścian wydobywczych. Zmiana sposobu postrzegania zmechanizowanych ścian wydobywczych po wprowadzeniu ich w górnictwie węglowym w USA $[1,2]$, potem w Australii i kolejno w innych krajach (np. Rosja, Chiny) doprowadziły do wzrostu dobowego wydobycia surowca ze ścian i tym samym wzrostu dobowych postępów ścian. W ślad za tym musiało pójść zwiększenie dobowych postępów przodków chodnikowych, ponieważ kolejna ściana musi być przygotowana, zanim poprzednia osiągnie linię swojego zatrzymania. Powiedzenie „czas to pieniądz” znajduje potwierdzenie w odniesieniu do przygotowania pola ścianowego do wydobycia - bardzo kosztowne wyposażenie wysokowydajnego kompleksu ścianowego nie może bezproduktywnie czekać na przygotowanie wyrobisk dla kolejnej ściany [3]. Za- gadnieniu uzyskiwania wysokich postępów w drążeniu wyrobisk korytarzowych od dawna poświęca się w Polsce dużo uwagi [4, 5], w licznych światowych publikacjach pisze się o poprawie efektywności drążenia wyrobisk z zastosowaniem kombajnów typu Bolter Miner [6-16]. W najbardziej zaawansowanych technicznie i najproduktywniejszych kopalniach węgla kamiennego na świecie powszechną praktyką stało się stosowanie obudowy kotwowej jako mniej kosztownego sposobu zabezpieczenia wyrobisk korytarzowych. Połączenie rozwiązań technicznych pozwalających na mechaniczne urabianie w przodkach węglowych i węglowo-kamiennych z szybkim wykonywaniem obudowy kotwowej w przodku doprowadziło do stworzenia ściśle wyspecjalizowanych maszyn - kombajnów chodnikowych typu Bolter Miner. Maszyny te pozwalają na uzyskiwanie bardzo wysokich postępów w drążeniu wyrobisk korytarzowych - najlepszy odnotowany wynik to około $2500 \mathrm{~m} . b . / m i e s i a ̨ c ~ u z y s k a n y$ w 2018 roku w chińskiej kopalni Daliuta (Grupa Shenhua Shendong) [17]. W sprzyjających warunkach górniczo-geologicznych dobrze przygotowane przodki są w stanie uzyskiwać postępy 6-8 m.b./h. W 2019 roku uruchomiono w celach doświadczalnych także w Polsce przodek chodnikowy z kombajnem typu Komatsu/Joy Global 12CM30 [18]. 
W artykule przedstawiono analizę wymagań i ograniczeń dotyczących efektywnego stosowania maszyn typu Bolter Miner.

\section{GENEZA I BUDOWA KOMBAJNÓW TYPU BOLTER MINER}

Kombajny typu Bolter Miner są wynikiem wieloletnich poszukiwań rozwiązania problemu wysokiej wydajności urabiania mechanicznego w przodkach węglowych i konieczności możliwie szybkiego zabezpieczenia stropu i ociosów drążonego wyrobiska.

\subsection{Zanim powstał Bolter Miner}

Obecna konstrukcja kombajnu typu Bolter Miner to połączenie na jednym podwoziu maszyny urabiającej typu Continuous Miner z wielogłowicowym urządzeniem kotwiącym.

W przeszłości podejmowano próby rozdzielenia w czasie i przestrzeni urabiania przodka z kotwieniem stropu z zastosowaniem zmechanizowanej obudowy kroczacej jako obudowy tymczasowej pomiędzy strefą urabiania (przodkiem) a strefą wykonywania kotwienia stropu. Rozwiązanie to stosowane w przodkach systemu komorowo-filarowego w USA [19, 20] nie potwierdziło swoich zalet i dość szybko z niego zrezygnowano. W europejskim górnictwie podejmowano próby zastosowania urządzeń do drążenia przodków z urabianiem mechanicznym i nadążnym wykonywaniem obudowy kotwowej jednym urządzeniem (AVSA) - także te próby nie zakończyły się sukcesem.

$\mathrm{Na}$ potrzeby dynamicznie rozwijanego australijskiego górnictwa węglowego firma Joy opracowała w latach 80. XX wieku urządzenie nazwane Joy Sump Shearer (JSS) (rys. 1) [21]. Maszyna przeznaczona była do drążenia wyrobisk o przekroju prostokątno- -łukowym z kotwieniem stropu w bezpośredniej bliskości czoła przodka (1,5 m). Stosowano dwie kotwiarki, a przekrój poprzeczny wyrobiska dobrano ze względu na optymalne wykorzystanie kotwiarek. Maszyna wyposażona była w dwa organy urabiające osadzone na ramionach w podobny sposób jak w przypadku kombajnów ścianowych.

Organy te umożliwiały urabianie stropu (z przycinaniem kamienia) z łukowym sklepieniem. Minimalizowało to ilość urabianego w stropie kamienia, ponieważ w tamtym czasie w górnictwie australijskim wybierano ściany węglowe o wysokości 2,2-2,8 m. Wzrost miąższości eksploatowanych pokładów i ograniczone korzyści stosowania JSS spowodowały, że zaniechano tego rozwiazania.

W USA i australijskim górnictwie węglowym system ścianowy, zwłaszcza od granic, jest traktowany jako kolejny etap rozwoju systemu komorowo-filarowego $\mathrm{z}$ wybieraniem filarów węglowych. Do mechanicznego wybierania węgla w tych systemach od lat 40 . XX wieku są stosowane różnego typu maszyny, które w odróżnieniu od systemów mechanizacyjnych $\mathrm{z}$ urabianiem materiałami wybuchowymi, nazwano Continuous Miner [5]. Od kilkudziesięciu lat dominują wśród tych maszyn kombajny z liniowym organem urabiającym na całą szerokość zabioru. W komorowo-filarowych systemach eksploatacji maszyny te pracują w układzie wieloprzodkowym z naprzemiennym urabianiem stropu i jego kotwieniem odrębną samobieżną maszyną kotwiącą. Takie też rozwiązanie zastosowano do drążenia chodników na potrzeby przygotowania ścian wydobywczych. W praktyce okazało się jednak, że występują duże straty czasu związane $\mathrm{z}$ wymianą maszyn w przodku - po urobieniu calizny na bezpieczną głębokość kombajn wycofywał się z przodka, aby wycofywał się z przodka, robiąc miejsce maszynie kotwiącej. Alternatywą, często wymuszaną warunkami górniczo-geologicznymi, było kotwienie stropu ręcznymi kotwiarkami bezpośrednio po jego odsłonięciu.

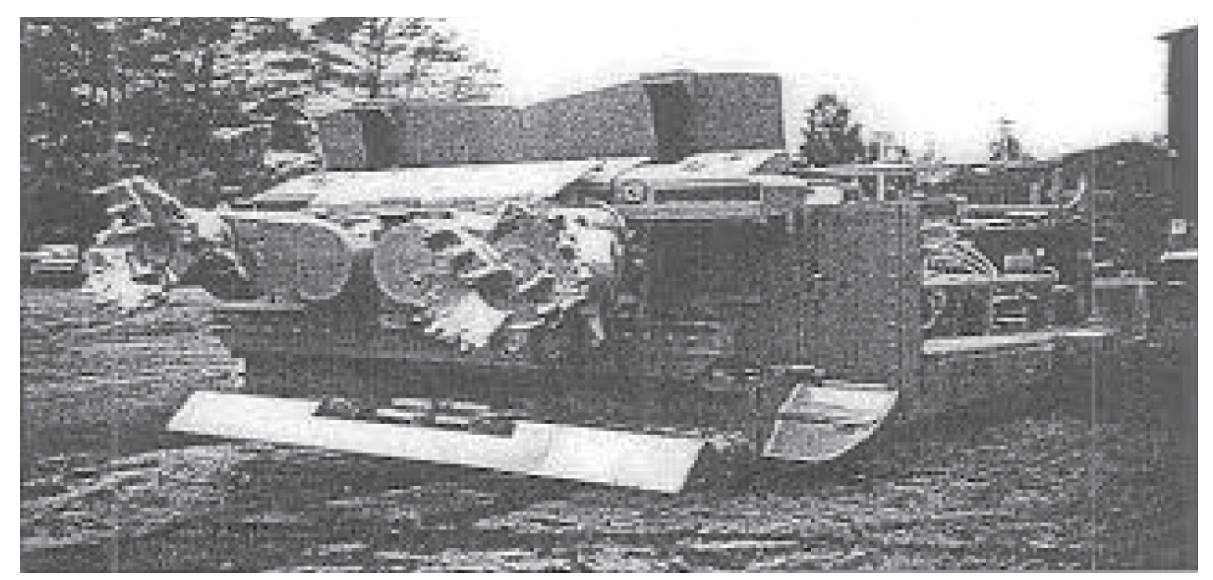

Rys. 1. Joy Sump Shearer [21] 


\subsection{Idea kombajnu typu Bolter Miner}

Pod koniec lat 80. XX wieku zrodziła się idea wyposażenia kombajnu typu Continuous Miner w stację kotwiarek, które umożliwiałyby jednoczesne wiercenie i kotwienie kilkoma kotwiarkami stropu i ociosów wyrobiska. Pierwsze urządzenie tego typu ABM 20 zastosowane w australijskiej kopalni Tahmoor [3] zostało opracowane w firmie Voest Alpine Bergtechnik (obecnie: Sandvik). Wdrożenie to zakończyło się sukcesem i bardzo szybko kombajny typu Bolter Miner rozpowszechniły się w światowym górnictwie węglowym, wszędzie tam, gdzie występują warunki do ich efektywnego stosowania. Współcześnie maszyny te stosowane są na dużą skalę w kopalniach eksploatujących węgiel kamienny systemem ścianowym w Australii, USA, Chinach czy Rosji. Pojedyncze maszyny są stosowane w innych krajach, w zanikającym europejskim górnictwie węglowym wdrażano je w Czechach i, ostatnio, w Polsce. Duża moc liniowego organu urabiającego i stabilność maszyny spowodowała, że podobnie jak maszyny urabiające pełnoprzekrojowe (borer miner) kombajny typu Bolter Miner stosowane są w eksploatacji (wybieraniu) niektórych innych kopalin miękkich (sól kamienna, sól potasowa, soda pasemkowa) w systemach wybierania długimi chodnikami.

Obecnie co najmniej trzech światowych producentów oferuje maszyny typu Bolter Miner (rys. 2).

Podobne maszyny oferowane są przez innych producentów, ale brak informacji o ich stosowaniu.

Kombajny typu Bolter Miner są wciąż doskonalone w kierunku poprawy wydajności drążenia, bezpieczeństwa i ergonomii pracy.

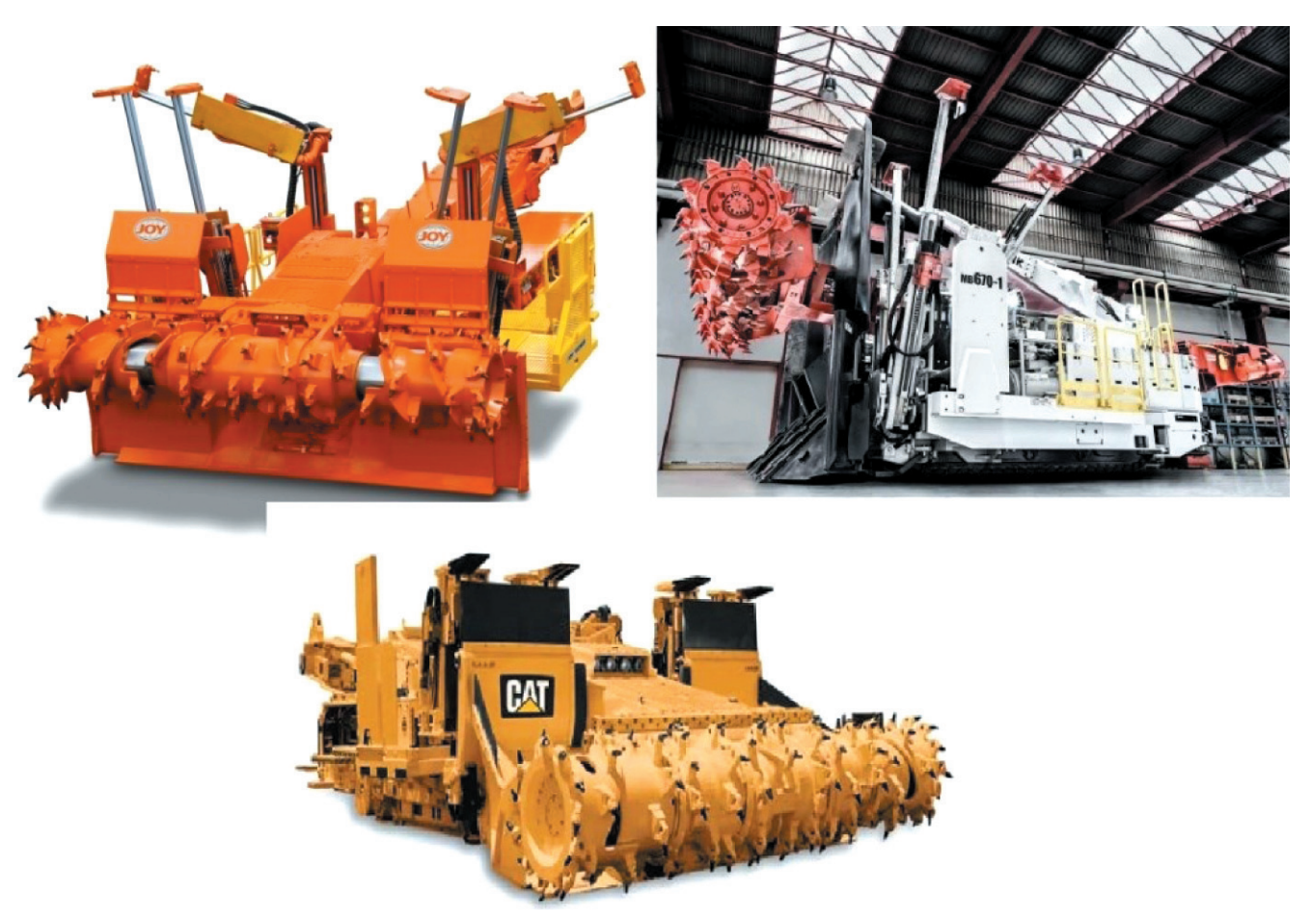

Rys. 2. Kombajny typu Bolter Miner produkcji Joy 12CM30, Sandvik MB670 i CAT CM845 [22-24]

\section{SYSTEM TECHNICZNY PRZODKA Z KOMBAJNEM TYPU BOLTER MINER}

W okresie rozwoju kombajnów typu Bolter Miner zdobyto doświadczenia i wypracowano system techniczny umożliwiający bardzo efektywne drążenie węglowych i węglowo-kamiennych wyrobisk korytarzowych o przekroju prostokątnym $\mathrm{z}$ zastosowaniem obudowy kotwowej. Kluczowym elementem systemu jest kombajn.

\subsection{Budowa i podstawowe cechy kombajnów typu Bolter Miner}

Kombajn typu Bolter Miner to połączenie na wspólnej platformie (podwoziu) [25-27] dwóch urządzeń:

- maszyny urabiająco-ładującej umożliwiającej odtransportowanie urobku poza przodek (maszynę),

- stacji kotwiącej wyposażonej w kilka głowic kotwiących, umożliwiającej równoczesne kotwienie stropu i ociosów (liczba głowic waha się od 4 do 6 sztuk). 


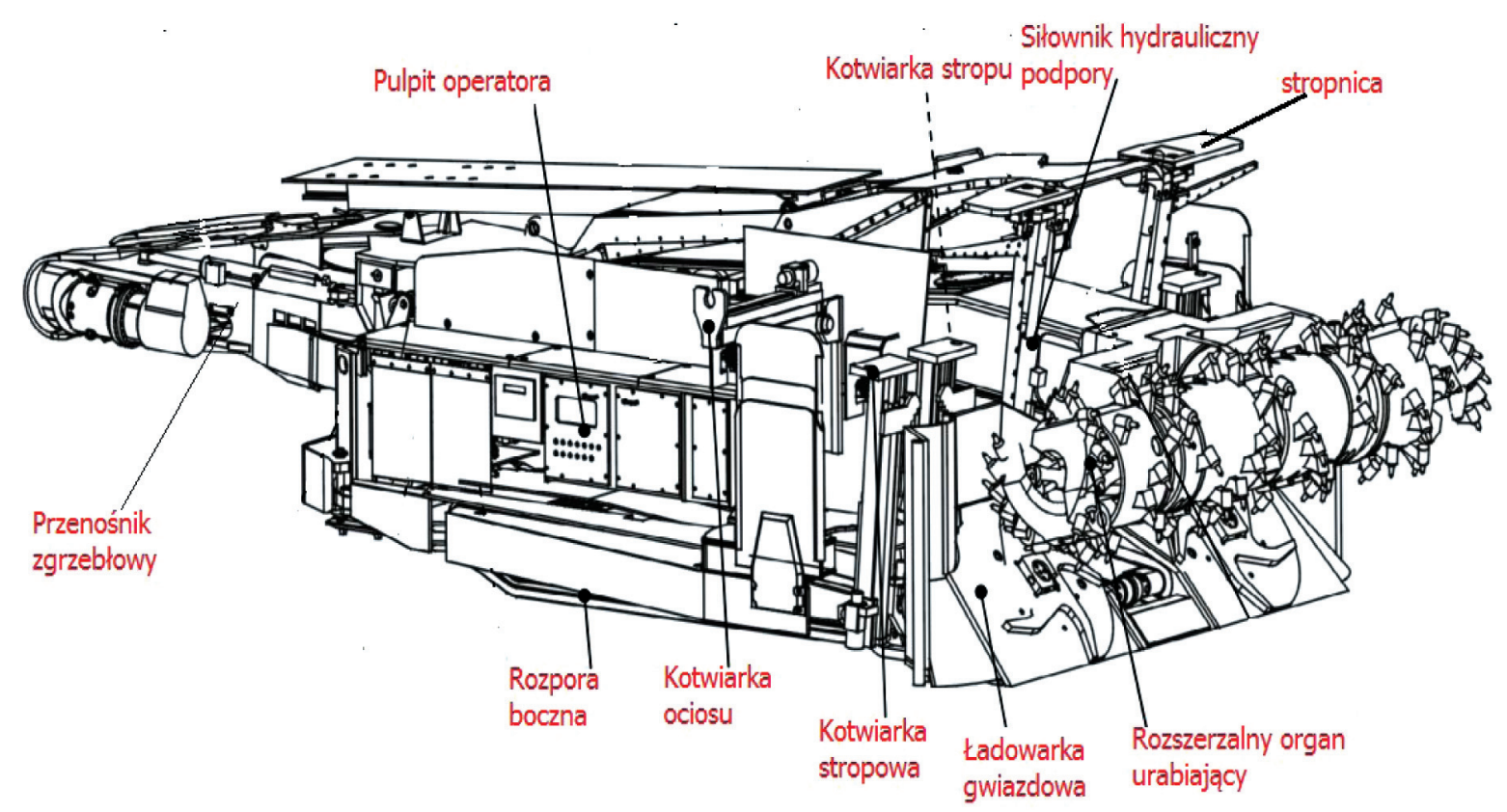

Rys. 3. Podstawowe elementy kombajnu typu Bolter Miner (opracowanie wtasne na podstawie [18])

Głównym założeniem konstrukcyjnym było maksymalne skrócenie czasu trwania podstawowych grup operacji realizowanych w przodku przez zwiększenie wydajności urabiania i równoległe wiercenie i kotwienie wielu kotwi. Podstawowe elementy kombajnu typu Bolter Miner firmy Sandvik pokazano na rysunku 3.

W odróżnieniu od podobnych kombajnów typu Continuous Miner cechą charakterystyczną maszyn typu Bolter Miner jest rozszerzalny organ urabiający. Rozwiązanie to ma na celu umożliwienie wycofania kombajnu po wydrążeniu długiego wyrobiska w sytuacji jego poziomej konwergencji. Aby poprawić efektywność drążenia i wydłużenia udziału czasu przeznaczonego na urabianie, dąży się do równoległego wykonywania czynności urabiania/ładowania urobku i kotwienia stropu i ociosów wyrobiska. W trakcie kotwienia kotwiarki muszą być utrzymywanie w stabilnej pozycji. Maszyny Bolter Miner firmy Sandvik wyposażone są w wysuwany zespół urabiająco-ładujący (organ i stół ładowarki) umożliwiający równoległe urabianie i kotwienie. W celu zapewnienia stateczności podwozia z kotwiarkami jest ono stabilizowane rozporami do ociosów i stropnicą obudowy tymczasowej do stropu. Trzy wysuwne podpory ułatwiają poziomowanie maszyny.

Maszyny innych producentów nie były wyposażone w wysuwny zespół urabiająco-ładujący i z tego powodu możliwość równoczesnego urabiania i kotwienia jest praktycznie niemożliwa - skrócenie czasu trwania podstawowego cyklu drążenia uzyskuje się przez skrócenie czasu trwania poszczególnych czynności i operacji.
Maszyna jest wyposażona w zintegrowany układ odpylający.

Ze względu na dużą moc silników organu urabiającego (łącznie ponad ok. $300 \mathrm{~kW}$ ) maszyny typu Bolter Miner, dla zachowania stateczności, muszą mieć stosunkowo dużą masę (od $80 \mathrm{Mg}$ do ponad $100 \mathrm{Mg}$ ) przy ograniczonych gabarytach. Powoduje to występowanie stosunkowo dużych nacisków na spąg wyrobiska. W związku z brakiem możliwości przemieszczania organu urabiającego w płaszczyźnie poziomej konieczne są manewry kombajnem w celu jego precyzyjnego ustawienia (pozycjonowania) przed rozpoczęciem urabiania, a zwłaszcza kotwienia. W warunkach mniej wytrzymałych spągów oznacza to możliwość grzęźnięcia kombajnu i wynikające $\mathrm{z}$ tego straty czasu dostępnego, przeznaczonego na urabianie/kotwienie.

Należy zauważyć, że maszyny typu Bolter Miner są bardzo wrażliwe na poprzeczne nachylenie pokładu (dopuszczalne nachylenia poprzeczne nie przekraczają $5^{\circ}$ ), ponieważ występują problemy z utrzymaniem stateczności kierunkowej maszyny. Dodatkowo nadmierne pochylenie poprzeczne spągu powoduje późniejsze problemy z transportem urządzeń i pracą instalacji zabudowanych w takich chodnikach.

\subsection{Systemy odstawy urobku i zasilania przodka}

Standardowo kombajny typu Bolter Miner współpracują w zakresie odstawy urobku z wozidłami typu Shuttle Car, które przewożą urobek do samojezdnej stacji rozładowczo-kruszącej (Feeder-Breaker), jak pokazano na rysunku 4. 


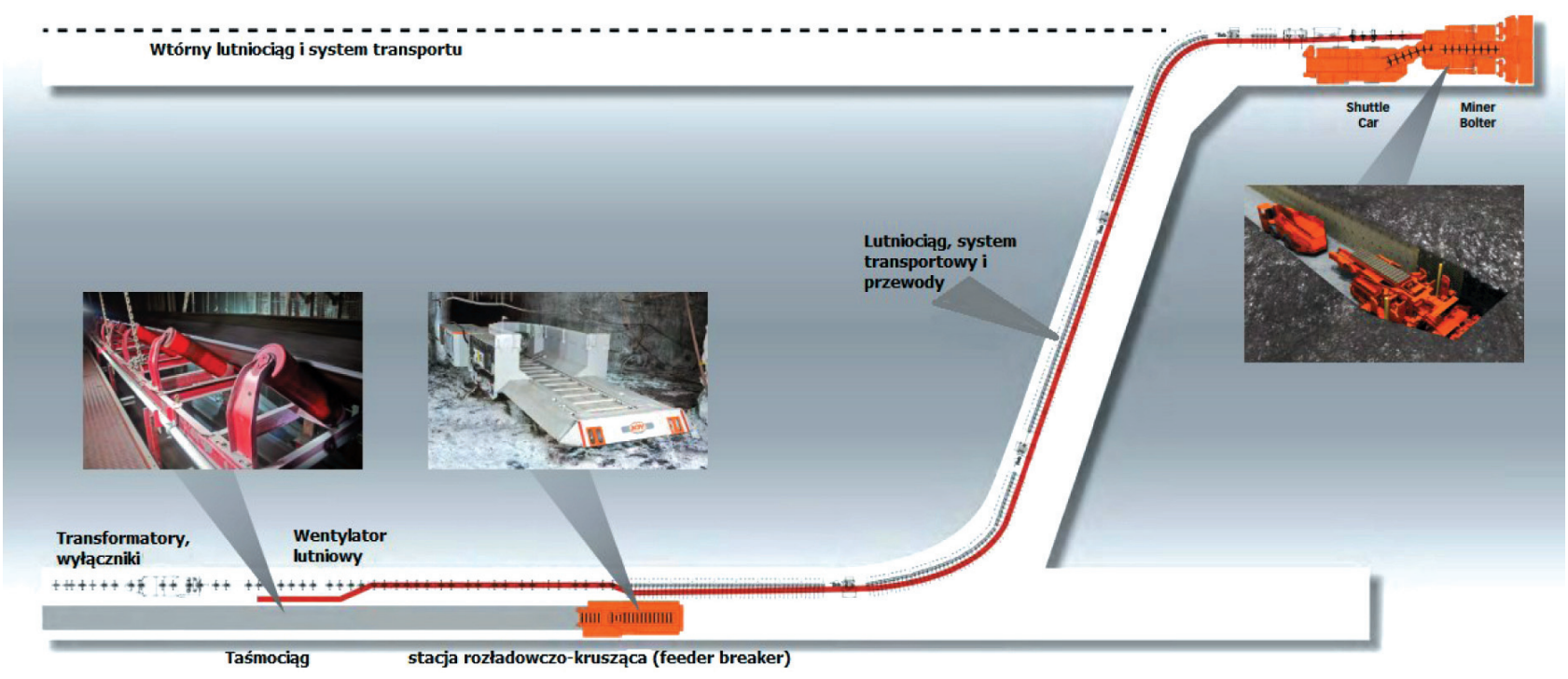

Rys. 4. Najbardziej rozpowszechniony układ technologiczny przodka z kombajnem typu Bolter Miner (opracowanie wtasne na podstawie [22])

Zadaniem stacji rozładowczo-kruszącej jest przygotowanie urobku do dalekiego transportu przenośnikiem taśmowym przez jego skruszenie i wyrównanie strumienia urobku. Zaletą takiego rozwiązania jest uniezależnienie pracy maszyny urabiającej od ciągłości pracy odstawy taśmociągami. Wozidło typu Shuttle Car (czasem dwa lub więcej) spełniają funkcję „elastycznego połączenia” - ruchomego zbiornika (zbiorników) retencyjnego.

Od kilku lat podejmuje się $\mathrm{z}$ różnym skutkiem $\mathrm{z}$ zastosowaniem do transportu urobku wieloczłonowych elastycznych, przegubowych przenośników taśmowych (np. system FCT f-my Komatsu) [23]. Rozwiązanie to nie jest stosowane $\mathrm{w}$ górnictwie australijskim, ale opisywane są jego zastosowania w górnictwie węglowym USA, gdzie stosuje się układy trzech, a nawet więcej równoległych chodników przyścianowych połączonych pomiędzy sobą przecinkami (rys. 5).
Rzadziej spotykane są rozwiązania z podwieszaniem od kombajnu podajnika podwieszanego (taśmowego lub zgrzebłowego) przeładowującego urobek przenośnik taśmowy, ponieważ rozwiązanie takie utrudnia pozycjonowanie kombajnu i dodatkowo zmienia rozkład nacisków na spąg - w warunkach słabszych spągów może to być dodatkową przyczyną niszczenia spągu i grzęźnięcia maszyny. Każde rozwiązanie z jakąś formą retencji urobku pomiędzy kombajnem typu Bolter Miner a stacjonarną odstawą taśmową jest rozwiązaniem korzystnym ze względu na charakterystyki transportowe urządzeń. Kombajn ma wysoką wydajność chwilową (do $35 \mathrm{Mg} / \mathrm{min}$.), podaje strugę urobku o tej intensywności przez kilka minut. Bez retencji stacjonarny przenośnik taśmowy musiałby mieć podobną chwilową zdolność transportową, co oznacza, przy charakterystyce pracy przenośników taśmowych znaczne przewymiarowanie urządzenia.

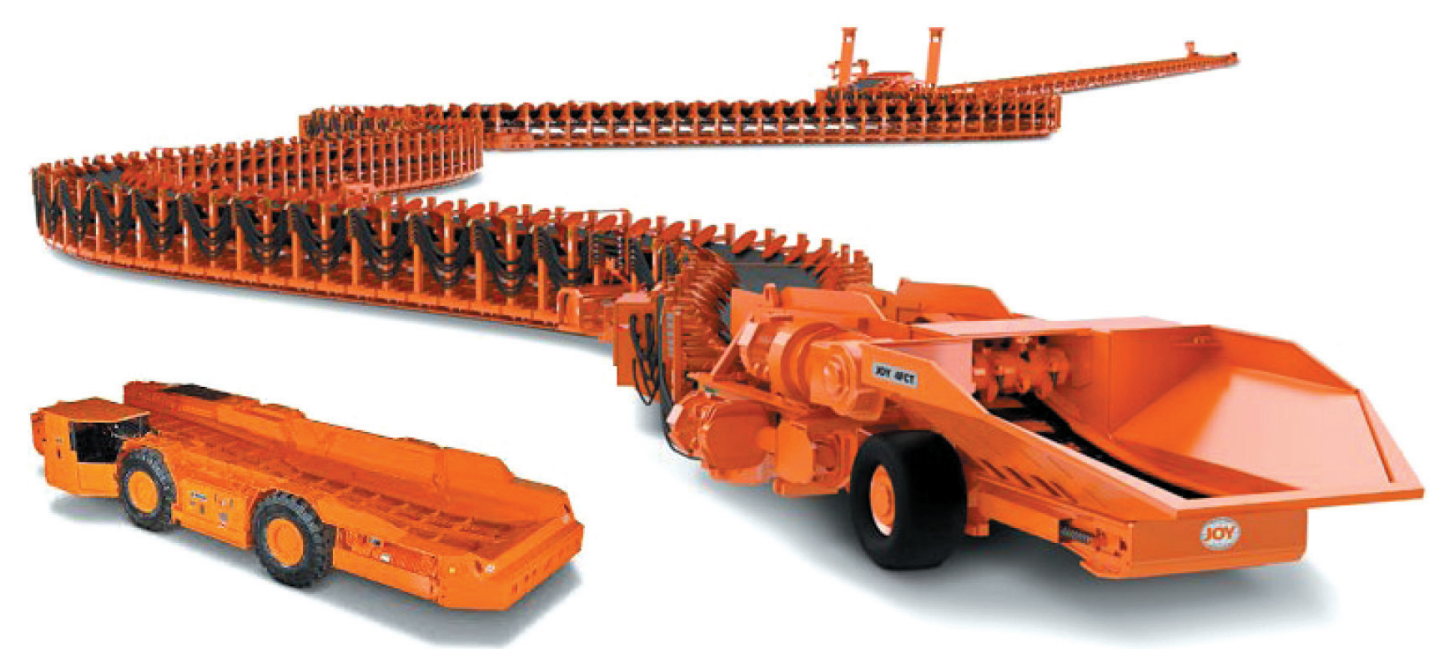

Rys. 5. Elastyczny przenośnik taśmowy FCT firmy Komatsu/Joy Global i wozidło typu Shuttle Car [23] 
Zaletą stosowania kotwienia stropu i ociosów jest znacznie mniejsze zapotrzebowanie ma materiały w porównaniu z wyrobiskami drążonymi w obudowie podporowej, a tym samym mniejsze wymagania wobec systemów transportowych.

\subsection{Inne systemy i instalacje}

Maszyna typu Bolter Miner stawia duże wymagania w zakresie zasilania w media.

Bardzo ważne jest doprowadzenie do przodka wody technologicznej o odpowiednich parametrach (wydatek, ciśnienie i czystość).

Ze względu na dużą moc zainstalowanych na maszynie Bolter Miner silników elektrycznych wysokie wymagania stawiane są także sieci elektroenergetycznej.

Niezbędnym systemem technicznym w drążeniu wyrobisk korytarzowych jest system przewietrzania przodka w ramach tzw. wentylacji odrębnej składającej się z wentylatora zabudowanego w opływowym prądzie powietrza (tj. prądzie powietrza, którego ruch wymuszany jest wentylatorami zabudowanymi przeważnie na powierzchni kopalni podziemnej). Do przodka od wentylatora doprowadza się świeże po- wietrze przewodami wentylacyjnymi (rzadziej w przypadku kombajnów typu Bolter Miner stosuje się odprowadzenie powietrza zużytego).

\section{WYMAGANIA I OGRANICZENIA STOSOWANIA KOMBAJNÓW TYPU BOLTER MINER}

Dla efektywnej pracy kombajnów typu Bolter Miner niezbędne jest spełnienie wymagań technicznych, w tym warunków górniczo-geologicznych.

\subsection{Wymagania dla kombajnów typu Bolter Miner}

Na rysunku 6 pokazano podstawowe grupy wymań dla efektywnej pracy kombajnów typu Bolter Miner.

Wymienione wyżej wymagania w zakresie doboru systemu mechanizacyjnego drążonego wyrobiska korytarzowego muszą być uwzględnione już na etapie planowania i projektowania. Zaplanowany i przygotowany powinien być także proces doboru załogi i jej szkolenia.

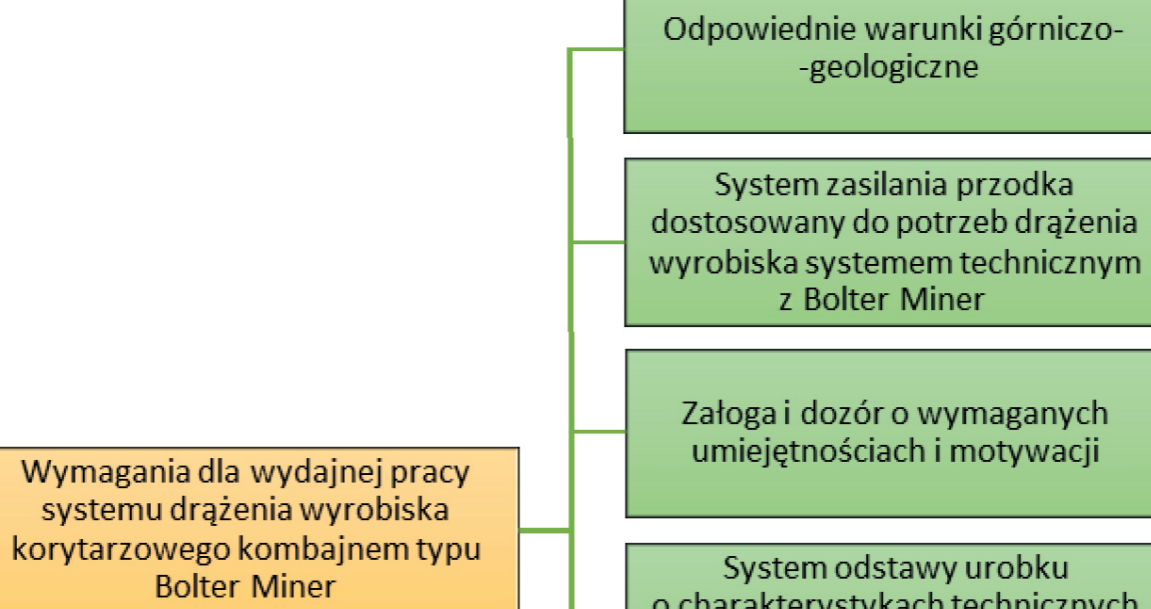

\section{Odpowiednie warunki górniczo-} -geologiczne

System zasilania przodka dostosowany do potrzeb drążenia wyrobiska systemem technicznym z Bolter Miner

Załoga i dozór o wymaganych umiejętnościach i motywacji

Rys. 6. Wymagania dla wydajnej pracy kombajnu typu Bolter Miner 


\subsection{Czynniki ograniczające efektywność drążenia wyrobiska korytarzowego kombajnem typu Bolter Miner}

Każdy system techniczny w górnictwie ma swoje ograniczenia konstrukcyjne (określane przeważnie jako dopuszczalne parametry robocze). Eksploatacja takiego systemu w warunkach przekroczenia dopuszczalnych parametrów pracy jest przeważnie powodem pogorszenia wyników operacyjnych. Wszystkie systemy mechanizacyjne w górnictwie są narażone na występowanie czynników ograniczających potencjalne możliwości techniczne systemu, tak jak pokazano na rysunku 7.

\section{Wewnętrzne ograniczenia systemu technicznego}

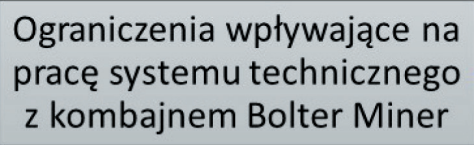

Rys. 7. Czynniki ograniczające wydajność systemu technicznego przodka drążonego kombajnem typu Bolter Miner (opracowanie wtasne na podstawie [9, 29, 28])

W przypadku zastosowania $\mathrm{w}$ drążeniu wyrobisk korytarzowych systemów mechanizacyjnych z kombajnami typu Bolter Miner występuje bardzo duża wrażliwość na te ograniczenia. Wynika to z wysokiej specjalizacji maszyny urabiającej przeznaczonej do pracy w stosunkowo wąskim spektrum warunków górniczo-geologicznych. Czas wykonywania obudowy kotwowej, wpływający istotnie na czas trwania podstawowego cyklu drążenia wyrobiska, wymaga otwartego podejścia w projektowaniu obudowy kotwowej obok zapewnienia bezpieczeństwa i stateczności wyrobiska w cyklu jego życia, istotne jest zastosowanie rozwiązań skracających czas trwania kompletnej operacji kotwienia.

\section{PODSUMOWANIE}

Duża moc liniowego organu urabiającego kombajnu typu Bolter Miner stwarza potencjalne możliwości uzyskiwania wysokich postępów (dobowych, miesięcznych itd.). Ze względu jednak na inne własności maszyny i realizowany przez nią drogi proces - ko- twienie, jest to możliwe w stosunkowo wąskim spektrum warunków górniczo-geologicznych. Kolejnym warunkiem uzyskiwania dużych postępów drążenia jest odpowiedni dobór współpracujących systemów technicznych, dostosowanych do możliwości kombajnu. Niezbędne są także wysokie umiejętności pracowników. Proces drążenia wyrobiska musi być odpowiednio zaplanowany, zorganizowany i zarządzany z uwzględnieniem możliwości maszyny Bolter Miner. Niespełnienie tych wymagań jest czynnikiem powodującym obniżenie uzyskiwanych wyników.

Warunkiem wstępnym jest zastosowanie tej maszyny w odpowiednich warunkach górniczo-geologicznych, co wymaga ich możliwie starannego rozpoznania przed podjęciem decyzji. Istotne jest także istnienie dobrych warunków do stosowania obudowy kotwowej - w niektórych warunkach może się okazać, że pracochłonność wykonania statecznej i bezpiecznej obudowy kotwowej będzie wymagała zastosowania innego rozwiązania.

Decyzja o zastosowaniu maszyny typu Bolter Miner wymaga bardzo starannych analiz kosztów i potencjalnych korzyści. 


\section{Literatura}

[1] Barczak T.M.: The History and Future of Longwall Mining in the United States, U.S. Department of the Interior, Bureau of Mines, 1992.

[2] Peng S.S.: Longwall Mining, $3^{\text {rd }}$ Edition, CRC Press/Balkema, Leiden 2020.

[3] www.coalage.com/features/faster-roadway-development/ [12.11.2020].

[4] Przybyła H., Chmiela A.: Technika i organizacja $w$ robotach przygotowawczych, Wydawnictwo Politechniki Śląskiej, Gliwice 2002.

[5] Zając E.: Organizacja produkcji w kopalni węgla kamiennego, Śląskie Wydawnictwo Techniczne, Katowice 1994.

[6] ACARP: Final Report: Australian Roadway Development Current Practises, Australian Coal Association Research Program, 17 October 2005.

[7] Baafi E., Gray G., Porter I., Rojas O.: The Modelling of Roadway Development to Support Longwall Mining, Australian Coal Association Research Program (ACARP). Simulation Modelling Services Pty Ltd, School of Civil, Mining and Environmental Engineering University of Wollongong, November 2009, http://www.undergroundcoal.com.au/roadway/pdf/ roadsim_final_report.pdf [11.01.2019].

[8] Banarjee S.: Performance evaluation of continuous miner based underground operation: An OEE based approach, „New Trends of Production Engineering” 2019, 2, 1: 596-603.

[9] Kizil M.S., McAllister A., Pascoe R.: Simulation of Development in Longwall Coal Mines, [w:] $11^{\text {th }}$ Underground Coal Operators Conference, University of Wollongong \& Australiasian Institute of Mining and Metallurgy, 2011: 91-98.

[10] Leeming J., Flook S., Altounyan P.: Bolter miners for longwall development, „Gluckauf” 2001, 137, 11: 633-638.

[11] Ma P., Qian D., Zhang N., Shimada H., Pan D., Huang K.: Application of bolter miner rapid excavation technology in deep underground roadway in inner Mongolia: A case study, ,Sustainability" 2020, 12 (7), art. no. 2588.

[12] Singh R.D.: Principles and practices of modern coal mining, New Age International Publishers, New Delhi 1997.

[13] Van Duin S., Donnelly P., Oxley I.: Automated bolting and mesh handling on a continuous miner, [w:] Final Report ACARP PROJECT C17018 - Stage 1, University of Wollongong, Wollongong (NSW, Australia) 2011.

[14] Wang H.: Present Status and Development of Mine Roadway Heading Technology and Equipment in China Coal Mine, „Journal of Coal Science and Technology" 2010, 38, 1: 57-62.

[15] Zhang D.: Development status and key technology of intelligent rapid driving technology in coal seam roadway, „Journal of Coal Engineering” 2018, 50, 5: 56-59.

[16] Wallman D.: Results of the First Trail Single Entry at Ellalong Colliery, ACIRL Report No. PR82.1 1982.
[17] Gao D., Liu Y., Luo W.: The Application of Speedy Drivage System in Daliuta Coal Mine, „IOP Conference Series: Materials Science and Engineering” 2019, 490, 062073, https:// iopscience.iop.org/article/10.1088/1757-899X/490/6/062073/pdf [10.12.2019].

[18] Korski J.: Zastosowanie kombajnów typu Bolter Miner w warunkach polskich kopalń - uwarunkowania i ograniczenia, „Inżynieria Górnicza” 2018, 4: 40-48.

[19] Korski J: Tymczasowe obudowy zmechanizowane $w$ drą̇eniu wyrobisk korytarzowych, [w:] D. Prostański, B. Polnik (red.): Innowacyjne techniki i technologie dla górnictwa: bezpieczeństwo - efektywność - niezawodność, Instytut Techniki Górniczej KOMAG, Gliwice 2020.

[20] Lesiecki W., Regulski W.: Urabianie złóż. Część 3. Urabianie kombajnami, Wydawnictwo „Śląsk”, Katowice 1957 („Górnictwo", t. 5).

[21] Ward B., Down M.: Gateroad Development in Thick Seams Using the Joy Sump Shearer, [w:] N. Aziz, B. Kininmonth, (eds.), Proceedings of the 1998 Coal Operators' Conference, Mining Engineering, University of Wollongong, 18-20 February 1998, https://ro.uow.edu.au/coal/274 [20.12.2020].

[22] CAT, https://www.cat.com/en_US/by-industry/mining/underground-mining.html [20.12.2020].

[23] KOMATSU, www.mining.komatsu/underground-mining/ room-pillar-entry-development [27.11.2020].

[24] SANDVIK, www.rocktechnology.sandvik/en/products/mechanical-cutting-equipment/ [27.07.2018].

[25] Klich A. (red.): Maszyny i urządzenia dla inżynierii budownictwa podziemnego. Wyrobiska korytarzowe i szybowe w górnictwie, „Śląsk” Sp. z o.o., Wydawnictwo Naukowe, Katowice 1999.

[26] Kotwica K., Klich A.: Maszyny i urządzenia do drą̇̇enia wyrobisk korytarzowych $i$ tunelowych, Instytut Techniki Górniczej KOMAG, Gliwice 2011

[27] Price D.: Demonstration of continuous cutting/bolting/rib-bolting development machine (the Voest-Alpine ABM 20 Bolter Miner), „Australia's Journal of Coal Mining Technology and Research" 1992, 35: 3-12.

[28] Korski J., Tobor-Osadnik K., Wyganowska M.: Internal Client and Efficiency in the Mining Process. World Multidisciplinary Earth Sciences Symposium (WMESS 2018) IOP Conference Series: Earth and Environmental Science 2019, 221, DOI: $10.1088 / 1755-1315 / 221 / 1 / 012102$.

[29] Korski J.: Czy podejście procesowe może podnieść efektywność polskiego górnictwa węgla kamiennego?, [w:] Materiały konferencyjne XXVI Szkoły Eksploatacji Podziemnej, Kraków 22-24.02.2017.

dr inz. JACEK KORSKI

Famur S.A.

ul. Armii Krajowej 51, 40-698 Katowice

JKorski@famur.com.pl

(C) 2020 Autor. Jest to publikacja ogólnodostępna, którą można wykorzystywać, rozpowszechniać i kopiować w dowolnej formie zgodnie z licencją Creative Commons CC-BY 4.0. 